\title{
HUBUNGAN POLA TIDUR DENGAN KONSENTRASI BELAJAR SISWA \\ DI KELAS Xd MA AL - QODIRI 1 JEMBER
}

Oleh :

\author{
Fika Indah Prasetya
}

\begin{abstract}
ABSTRAK
Tidur merupakan salah satu kebutuhan dasar manusia yang termasuk ke dalam kebutuhan fisiologis, tidur juga hal yang universal karena semua individu dimanapun ia berada membutuhkan tidur. Kesulitan tidur akan berdampak pada tingkat konsentrasi belajr dan bekerja, serta secara emosional akan menjadi mudah sedih dan depresi sehingga penulis ingin melakukan penelitian dengan judul “ Hubungan Pola Tidur dengan Konsentrasi Belajar di Kelas Xd MA Al - Qodiri 1 Jember". Penelitian ini mempunyai tujuan untuk menganalisis hubungan antara Pola Tidur dengan Konsentrasi Belajar.
\end{abstract}

Kata kunci : Pola tidur, konsentrasi belajar

\begin{abstract}
Sleep is one of the basic human needs whitch belong to the physiological needs, sleep also universal because all individuals wherever they are in need of sleep. Difficulty sleeping will have an impact on the level of concentration of study and work, and will be easy emotionally sad and depressed so I want to do research with the title "Sleep Patterns relationship with Concentration Study in Class Xd MA Al - Qodiri 1 Jember". This study aims to analyze the relationship between the concentration of Sleep Patterns Study.
\end{abstract}

Keywords : Sleep Patterns,Concentration of Learning 


\section{PENDAHULUAN}

\section{Latar Belakang}

Kebutuhan dasar manusia merupakan sesuatu yang harus di penuhi untuk meningkatkan derajat kesehatan. Menurut teori Maslow manusia mempunyai lima kebutuhan dasar yang paling penting meliputi : kebutuhan fisiologis, kebutuhan keselamatan dan keamanan, kebutuhan cinta dan rasa memiliki, kebutuhan rasa harga diri, dan kebutuhan aktualisasi diri (Perry\&Potter,2006).

Tidur merupakan salah satu kebutuhan dasar manusia yang termasuk ke dalam kebutuhan fisiologis, tidur juga hal yang universal karena semua individu dimanapun ia berada membutuhkan tidur (Kozier,2000). Menurut Potter dan Perry (2006) juga mengatakan kebutuhan untuk tidur, sangat penting bagi kualitas hidup semua orang. Tiap individu memiliki kebutuhan tidur yang berbeda dalam kuantitas dan kualitasnya.

Berdasarkan perbandingan tempat kejadian, hasil survey yang di lakukan di suatu rumah sakit di Amerika mengatakan bahwa stimulus yang dapat menganggu tidur di rumah sakit meliputi kesulitan menemukan posisi nyaman (62\%), nyeri (58\%), cemas (30\%), takut (25\%), lingkungan tidak dikenal (18\%), kebisingan kantor perawatan (25\%), temperature ( $17 \%)$, suara Rebut (17\%), tempat tidur yang tidak nyaman (10\%), kebiasaan terganggu (20\%), dan lain-lain (15\%). Hasil survey yang dilakukan di rumah sakit Cipto Mangunkusumo menyatakan yang dapat menyebabkan gangguan pola tidur meliputi nyeri $(34,5 \%)$, cemas penyakit berulang $(17,24 \%)$, cemas tidak kembali normal (15,5\%), cemas tindakan perawat $(3,5 \%)$, demam (2\%) dan lain- lain (25.8\%) termasuk cemas keluarga di rumah, udara panas, tidak nyaman, pusing, berkeringat,lelah (Roman,2010).

Berdasarkan hasil studi pendahuluan tanggan 27 Oktober 2013 di MA Al-Qodiri kelas X, terdiri dari empat kelas yang berjumlah keseluruhan 140 siswa. Berdasarkan hasil wawancara pada 10 responden,diperoleh data 7 siswa (70\%) mengalami gangguan. 
Gangguan pola tidur yang dialami oleh siswa seperti sulit untuk memulai tidur. Sedangkan data tentang konsentrasi belajar diperoleh 6 siswa (60\%) yang mengalami gangguan konsentrasi belajar sedangkan 4 siswa (40\%) tidak mengalami gangguan konsentrasi belajar.

Banyak siswa yang tidur larut malam untuk mengerjakan tugas sekolah atau belajar untuk ulangan. Mereka memilih tidur larut malam dan mengerjakan tugas atau belajar untuk ulangan. Ada juga yang memilih untuk tidur sampai jam tertentu lalu bangun subuh hari dan mengerjakan tugas atau belajar untuk ulangan. Sebenarnya hal tersebut tidak baik karena jika pola tidurnya tidak baik maka akan kesulitan untuk berkonsentrasi dan juga berpengaruh bagi kesehatan siswa. Karena pada jam-jam malam tertentu bagian dalam tubuh akan bekerja selama tubuh kita tidur maka proses-proses yang terjadi didalam tubuh tidak akan terjadi dan menyebabkan siswa mengalami gangguan kesehatan.

Studi ini menunjukan bahwa hormon melatonin pada remaja diproduksi di malam hari, berbeda dengan anak-anak dan orang dewasa. Hormon inilah yang menyebabkan remaja lebih sulit untuk tidur lebih awal. Bila hal ini terus menerus terjadi, disertai dengan beban aktivitas fisik yang berlebih, remaja akan menjadi stres karena hanya memikirkan hal -hal sepele yang membuatnya tidak dapat tidur. Selain itu, kesulitan tidur akan berdampak pada tingkat konsentrasi belajar dan bekerja, serta secara emosional akan menjadi mudah sedih dan depresi. Untuk mengatasinya, Anda dapat menetapkan waktu tidur yang teratur. Bagi usia remaja dan dewasa, waktu terbaik untuk tidur ialah antara pukul 9-12 malam. Asumsikan Anda tidur 7 jam, maka Anda akan terbangun pukul 4-5 pagi. Jika aktivitas Anda baru dimulai lebih siang, pergunakan waktu di pagi hari untuk aktivitas lain, misalnya belajar. Lalukan pola tidur ini terus selama seminggu hingga tubuh akhirnya terbiasa. Lakukan juga olahraga rutin pada sore hari, serta kurangi konsumsi stimulan serta kopi dan rokok saat hendak tidur. Selain itu buatlah suasana kamar menjadi nyaman serta 
buatlah pikiran Anda lebih rileks, yang terpenting, bila Anda mengantuk pada siang hari, hindari tidur siang. Ingatlah diri bahwa Anda sedang berusaha untuk membentuk pola tidur Anda.(Perry\&potter,2006).

\section{METODE PENELITIAN}

Berdasarkan

tujuan

penelitian, desain penelitian yang digunakan adalah analitik korelasional. Berdasarkan jenisnya, peneliti melakukan penelitian studi korelasi ( mengkaji hubungan antar variabel) dengan pendekatan CrossSectional yaitu jenis penelitian yang menekankan waktu pengukuran atau observasi data variabel independen dan dependen hanya satu kali pada satu saat.

Pada penelitian ini bertujuan untuk mengetahui hubungan pola tidur dengan konsentrasi belajar siswa di kelas X MA Al - Qodiri 1 Jember.

\section{HASIL PENELITIAN}

Berdasarkan hasil penelitian hubugan pola tidur dengan konsentrasi belajar siswa di kelas XD di MA Al - Qodiri 1 Jember yang berjumlah 40 siswa. Setelah data terkumpul maka data tersebut akan di bagi menjadi data umum dan data khusus. Data umum terdiri dari umur, sering tidur di kelas, dan jam tidur. Sedangkan data khusus terdiri dari pola tidur dan konsentrasi belajar.

XD MA Al-Qodiri 1 Jember berusia 16 tahun $(55 \%)$

\section{Data Khusus}

1. Pola tidur

Tabel 5.2 distribusi frekuensi responden berdasarkan pola tidur di kelas XD MA AlQodiri 1 Jember.

\begin{tabular}{|c|c|c|c|}
\hline $\begin{array}{l}\mathrm{N} \\
\mathrm{o}\end{array}$ & $\begin{array}{l}\text { Pola } \\
\text { tidur }\end{array}$ & $\begin{array}{l}\text { Frekue } \\
\text { nsi (f) }\end{array}$ & $\begin{array}{l}\text { Prosenta } \\
\text { se }(\%)\end{array}$ \\
\hline 1 & $\begin{array}{l}\text { Ada } \\
\text { gangguan }\end{array}$ & 30 & 75 \\
\hline 2 & $\begin{array}{l}\text { Tidak } \\
\text { ada } \\
\text { gangguan }\end{array}$ & 10 & 25 \\
\hline & Jumlah & 40 & 100 \\
\hline
\end{tabular}

di atas dapat diketahui bahwa sebagian besar responden di kelas $\mathrm{Xd}$ MA Al- Qodiri 1 Jember mengalami 
gangguan pola tidur sebanyak 30 responden $(75 \%)$.

\section{Konsentrasi Belajar}

Tabel 5.3 distribusi frekuensi responden berdasarkan konsentrasi belajar di kelas Xd MA Al- Qodiri 1 Jember.

\begin{tabular}{|l|l|l|l|}
\hline N & $\begin{array}{l}\text { konsent } \\
\text { rasi } \\
\text { belajar }\end{array}$ & $\begin{array}{l}\text { Frekue } \\
\text { nsi (f) }\end{array}$ & $\begin{array}{l}\text { Prosent } \\
\text { ase (\%) }\end{array}$ \\
\hline 1 & Kurang & 30 & 75 \\
\hline 2 & Cukup & 3 & 7,5 \\
\hline 3 & baik & 7 & 17,5 \\
\hline jumlah & 40 & 100 \\
\hline
\end{tabular}

Berdasarkan data yang di peroleh tabel 5.3 di atas dapat diketahui bahwa sebagian besar responden di kelas Xd MA Al- Qodiri 1 Jember yang mempunyai konsentrasi belajar kurang sebanyak 30 responden (75\%)

\section{Analisis data}

Berdasarkan hasil uji analisa data dengan menggunakan uji wiloxon diperoleh hasil pvalue : $0,008 \alpha=0,05$ sehingga disimpulkan H1 diterima, artinya ada hubungan pola tidur dengan konsentrasi belajar.

\section{PEMBAHASAN}

\section{Pola tidur}

Berdasarkan data pada tabel 5.3 di atas dapat diketahui bahwa pola tidur siswa di kelas Xd MA AlQodiri 1 Jember yang mengalami gangguan pola tidur sebanyak 30 responden (75\%), sedangkan yang tidak mengalami gangguan pola tidur sebanyak 10 responden (25\%).

Tidur adalah suatu keadaan relatif tanpa sadar dengan penuh ketenangan tanpa kegiatan yang merupakan urutan siklus yang berulang-ulang dan masing-masing menyatakan fase kegiatan otak dan badaniah yang berbeda. Pada seseorang yang dalam keadaan normal, maka kebutuhan akan dapat terpenuhi sesuai dengan tingkat perkembangan. Dari beberapa pendapat para ahli tentang tidur dapat disimpulkan bahwa tidur sangat penting bagi tubuh. Karena pada saat tidur sebagian organ tubuh termasuk otak akan beristirahat. Jika kita kurang tidur maka otak kita pun kurang istirahat, hal itu menyebabkan konsentrasi belajar menjadi terganggu. Jam biologis 
merupakan pengatur waktu internal dalam tubuh yang bekerja secara otomatis. Jam biologis manusia sudah terprogram secara genetik untuk menentukan waktu bangun tidur kita. Setiap orang memiliki jam biologis yang berbeda-beda tergantung pada umurnya. Jika kita melawan jam biologis maka akan berdampak buruk bagi kesehatan.

\section{Konsentrasi Belajar}

Berdasarkan data pada tabel 5.3 di atas dapat diketahui bahwa siswa di kelas Xd MA Al-Qodiri 1 Jember yang mempunyai konsentrasi belajar kurang sebanyak 30 responden $(75 \%)$, yang mempunyai konsentrasi belajar cukup sebanyak 3 responden $(7,5 \%)$, sedangkan yang mempunyai konsentrasi belajar baik sebanyak 7 responden $(17,5 \%)$.

Konsentrasi adalah pemusatan pikiran terhadap suatu hal dengan menesampingkan semua hal lain yang tidak berhubungan (Emon, 2009). Slameto (2003) berpendapat bahwa dalam belajar, berkonsentrasi berarti pemusatan pikiran terhadap suatu mata pelajaran dengan mengesampingkan semua hal lainnya yang tidak berhubungan dengan pelajaran. Djamarah (2008) mengungkapkan bahwa konsentrasi adalah pemusatan fungsi jiwa terhadap suatu objek. Misalnya konsentrasi pikiran, perhatian dan sebagainya. Dalam belajar diperlukan konsentrasi dalam perwujudan perhatian terpusat pada suatu pelajaran. Maka konsentrasi merupakan salah satu aspek pendukung siswa untuk mencapai prestasi yang baik. Apabila konsentrasi berkurang maka dalam mengikuti pelajaran di kelas maupun belajar secara pribadi pun dapat terganggu.

Berdasarkan teori yang ada faktor yang mempengaruhi konsentrasi belajar siswa adalah kesehatan. Kesehatan dapat dijaga dengan istirahat yang cukup. Apabila siswa kurang istirahat maka kesehatannya akan terganggu, sehingga mengakibatkan konsentrasi belajar siswa ikut terganggu.

Hubungan pola tidur dengan konsentrasi belajar di kelas Xd MA Al - Qodiri 1 Jember 
Menurut Yolanda Amirta ( 2007 ), makna dasar tidur adalah suatu keadaan dimana otak dan pikiran serta tubuh diberi kesempatan untuk beristirahat. Salah satu contoh pola tidur yang tidak baik adalah kurang tidur. Pada dasarnya penyebab kurang tidur disebabkan oleh diri kita sendiri. Menurut Carpenter dan Graham bahwa remaja sering kurang tidur karena adanya perubahan denyut jantung yang diakibatkan oleh perubahan hormon yang dihasilkan oleh otak. Selain itu, perkembangan teknologi seperti permainan lewat komputer, internet, vidio dan televisi juga menjadi penyebab utama kurangnya tidur pada siswa. Siswa itu sediri memerlukan waktu 9-10 jam tidur dalam sehari. Tetapi faktanya sekarang ini jam tidur siswa tidak sampai segitu lagi, semua itu dikarenakan oleh beberapa hal yang menyebabkan pola tidur yang tidak baik terjadi pada siswa. Tanpa mereka sadari penyebab pola tidur yang tidak baik dapat menjadi kebiasaan dalam kehidupan seharihari. Konsentrasi belajar adalah pemusatan pikiran, perhatian serta keasadaran terhadap suatu pelajaran dan mengesampingkan hal-hal yang tidak ada hubungannya dengan proses belajar.

Berdasarkan teori yang ada, kesehatan sangat berpengaruh pada konsentrasi belajar. Untuk menjaga kesehatan salah satu cara yang dilakukan adalah menjaga pola tidur yang baik. Berdasarkan data responden di kelas $\mathrm{Xd}$ yang mengalami gangguan pola tidur dengan konsentrasi belajar kurang sebanyak 30 responden (100\%), sedangkan responden yang tidak mengalami gangguan pola tidur dengan konsentrasi belajar baik sebanyak 7 responden (70\%). Hal tersebut menunjukkan bahwa pola tidur berhubungan dengan konsentrasi belajar siswa. Apabila pola tidur siswa buruk, secara tidak langsung akan mempengaruhi kesehatan siswa tersebut, yang nantinya akan mengakibatkan konsentrasi belajar siswa juga terganggu.

\section{KESIMPULAN DAN SARAN}

\section{Kesimpulan}


Pola tidur siswa di kelas Xd MA AlQODIRI 1 Jember sebagian besar mengalami gangguan pola tidur sebanyak 30 responden (75\%).

Konsentrasi belajar siswa di kelas Xd MA Al-Qodiri 1 Jember sebagian besar mempunyai konsentrasi belajar kurang sebanyak 30 responden (75\%).

Ada hubungan pola tidur dengan konsentrasi belajar siswa di kelas Xd MA Al-Qodiri.

\section{Saran}

Diharapkan lebih banyak literatur mengenai pola tidur dan konsentrasi belajar, serta ilmu kesehatan lainnya agar mempermudah dalam penyusunan skripsi.

Diharapkan ad program khusus bagi siswa sehingga konsentrasi belajar siswa tetap efektif, dan kegiatan belajar-mengajar siswa terus berjalan dengan baik.

Diharapkan perubahan dengan cara menjaga pola tidur yang baik agar tidak ada siswa yang tidur di sekolah pada waktu jam pelajaran sehingga konsentrasi belajar siswa di sekolah dapat menjadi efektif.

\section{DAFTAR PUSTAKA}

1. Potter dan Perry. 2006.Kebutuhan tidur manusia, Grawirasindo, Jakarta

2. Robinson .2008.Gangguan pola tidur manusia, Rajawali Pers, Bandung

3. Tartowo \& Wartonah.2006.Kebutuhan dasar manusia, Insomnia, Jogjakarta

4. Nugroho.2007.Aspek - aspek konsentasi belajar, Rinake Cipta, Jakarta

5. Syah.2003.Tahapan dalam belajar, Salemba Medika Jombang

6. Slamet, 2003, Cara meningkatkan konsentrasi belajar siswa, Rineka Cipta, Jakarta

7. Purwanto.2004.Karakteristik siswa dalam belajar,Alfabeta, Bandung

8. Nursalam. 2003. Metodologi Penelitian Keperawatan, Salemba Medika, Jakarta

9. Sugiyono. 2009. Statistic untuk penelitian. Alfabeta, Bandung 
10. Arikunto. 2008. Prodesur Penelitian Suatu Pendekatan. Rineka Cipta, Jakarta

11. Sugiyono. 2007. Metodologi Penelitian Kuantitaif Kualitatif dan $R \& D$, Alfabeta, Jakarta

12. Sugiyono. 2011. Metodologi Penelitian Kuantitatif Kualitatif dan $R \& D$, Alfabeta,Jakarta

13. Kozier, 2000. Kebutuhan Tidur Manusia, Grawirasindo, Jakarta

14. Yolanda Amirta, 2007. Aspek Konsentrasi Belajar, Rineka Cipta,Jakarta 
